\title{
PREDICTION OF SHEAR STRENGTH OF HIGH STRENGTH REINFORCED CONCRETE TEE BEAMS
}

Eng. Khaled Abdelsamee

Engineer, Sohage building house organization.

Dr. Mhamoud Hosni

Lecturer of Structural Eng., Civil eng. Dept, Assiut University.

Dr. Yehia A. Hassanean

Associate Professor of Structural Eng., Civil eng. Dept, Assiut

University, E-mail: Yehiamk@yahoo.com

Prof. Housni M. Sogier

Professor of Reinforced concrete structures, Civil eng. Dept,

Assiut University

(ReceivedOctober28, 2006 Accepted November 14, 2006 )

\begin{abstract}
Results of an theoretical investigation of the shear strength of reinforced concrete tee beams made from high strength concrete are summarized in this paper. In addition to the effect of both flange to web width ratio of tee beams and compressive strength of the concrete, the effect of other variables such as shear span to depth ratio, percentage of both tension steel and web reinforcement were taken into consideration in predicting shear strength of high strength reinforced concrete tee beams. Finite element method was used to analyze twenty six beams subjected to two point static loading. Proposed equation to estimate the shear strength of the analyzed beams was developed. The predicated shear strengths by the proposed equation were compared with Zustty, ACI code, Egyptian code.
\end{abstract}

\section{INTRODUCTION}

Egyptian code of practice ECCS 203, [1], estimates the value of ultimate shear strength as $3.0 \mathrm{~N} / \mathrm{mm}^{2}$ for the concrete compressive strength greater than 30 $\mathrm{MPa}$, Also, the Egyptian code considers only the effect of concrete compressive strength and ignores the effect of all variables that affect the ultimate shear strength of reinforced concrete beams. The Egyptian code evaluate the values of cracking and ultimate shear strength of the reinforced concrete beams having web reinforcement by the following equations:

$$
\begin{aligned}
& \mathrm{q}_{\mathrm{cr}}=0.24 \sqrt{\frac{\mathrm{F}_{\mathrm{cu}}}{\gamma_{\mathrm{c}}}} \quad \mathrm{N} / \mathrm{mm}^{2} \\
& \mathrm{q}_{\mathrm{u}}=0.70 \sqrt{\frac{\mathrm{F}_{\mathrm{cu}}}{\gamma_{\mathrm{c}}}} \leq 3 \mathrm{~N} / \mathrm{mm}^{2}
\end{aligned}
$$


Where : $\mathrm{F}_{\mathrm{cu}}$ cube compressive strength of the concrete.

$\gamma_{c}$ concrete strength reduction factor.

$\mathrm{q}_{\mathrm{cr}}$ cracking shear strength

$\mathrm{q}_{\mathrm{u}}$ ultimate shear strength

The ACI building code [2], based on experimental results of numerous beams their compressive strength was mostly below 41.0 MPa. Previous works have shown that the ratio of measured to predicate shear strength using ACI code equations decreases as the concrete compressive strength increases. ACI code underestimates the effect of longitudinal steel ratio and shear span to depth ratio. The ACI code evaluates both the cracking and ultimate shear strength of the beams in P.S.I. units as follows:

$$
\begin{aligned}
\mathrm{q}_{\mathrm{cr}} & =2 \sqrt{\mathrm{F}_{\mathrm{c}}^{\prime}} \\
\text { Or: } \mathrm{q}_{\mathrm{cr}} & =\left[1.90 \sqrt{\mathrm{F}_{\mathrm{c}}^{\prime}}+2500 \rho \frac{\mathrm{d}}{\mathrm{a}}\right] \leq 3.50 \sqrt{\mathrm{F}_{\mathrm{c}}^{\prime}}
\end{aligned}
$$

For R.C beams withoutshear reinforcenent:

$$
\mathrm{q}_{\mathrm{u}}=\left(3.5-2.5 \frac{\mathrm{a}}{\mathrm{d}}\right)\left[1.90 \sqrt{\mathrm{F}_{\mathrm{c}}^{\prime}}+2500 \rho \frac{\mathrm{d}}{\mathrm{a}}\right]
$$

For R.C. beams with shear reinforcement

$$
\mathrm{q}_{\mathrm{u}}=\mathrm{q}_{\mathrm{c}}+\mathrm{q}_{\mathrm{s}}
$$

Where: $F_{c}{ }^{\prime}$ cylinder compressive strength of the concrete.

$\rho$ the percentage of longitudinal reinforcement.

a/d the shear span to depth ratio.

Also, Zsutty [3], proposed the following equations to evaluate both the cracking and ultimate shear strength of the beams in P.S.I units:

$$
\begin{aligned}
q_{c r} & =59\left(\mathrm{~F}_{\mathrm{c}}^{\prime} \rho \frac{\mathrm{d}}{\mathrm{a}}\right)^{0.33} & & \\
q_{u} & =\frac{2.50}{\mathrm{a} / \mathrm{d}} 59\left(\mathrm{~F}_{\mathrm{c}}^{\prime} \rho \frac{\mathrm{d}}{\mathrm{a}}\right)^{0.33} & & \frac{\mathrm{a}}{\mathrm{d}}<2.50 \\
q_{u} & =63.40\left(\mathrm{~F}_{\mathrm{c}}^{\prime} \rho \frac{\mathrm{d}}{\mathrm{a}}\right)^{0.33} & & \frac{\mathrm{a}}{\mathrm{d}} \geq 2.50
\end{aligned}
$$

Based on curve fitting of the results of twenty five High strength reinforced beams tested under one point static loading Khaled A. M. et-al [4], proposed the following equations to calculate the cracking shear strength in P.S.I units:

$$
\mathrm{q}_{\mathrm{cr}}=1.365 \sqrt[3]{\mathrm{F}_{\mathrm{c} 28}}+583.4 \rho \frac{\mathrm{d}}{\mathrm{a}}
$$


Up to web reinforcement parameter, $\rho_{\mathrm{w}} \mathrm{f}_{\mathrm{yw}}$, equal to $5.419 \mathrm{~kg} / \mathrm{cm}^{2}$, the ultimate shear strength calculated by the following equation in P.S.I units:

$$
\mathrm{q}_{\mathrm{u}}=\mathrm{q}_{\mathrm{c}}+\rho_{\mathrm{w}} \mathrm{f}_{\mathrm{yw}}
$$

For beams having web reinforcement parameter bigger than $5.419 \mathrm{~kg} / \mathrm{cm}^{2}$ the ultimate shear strength can be calculated from the following equation in P.S.I units:

$$
q_{u}=q_{c}+\left(-6.70+1.90 \rho_{w} \cdot f_{y w}-0.086\left(\rho_{w} \cdot f_{y w}\right)^{2} \sqrt[4]{F_{c 28}}\right.
$$

The ultimate concrete shear strength $\mathrm{q}_{\mathrm{u}}$ can be expected by the following equations in P.S.I units:

$$
\begin{array}{lr}
\mathrm{q}_{\mathrm{c}}=\left(0.75+1.4 \frac{\mathrm{d}}{\mathrm{a}}\right) \mathrm{q}_{\mathrm{cr}} & \frac{\mathrm{a}}{\mathrm{d}} \leq 2.0 \\
\mathrm{q}_{\mathrm{c}}=\left(0.30+2.25 \frac{\mathrm{d}}{\mathrm{a}}\right) \mathrm{q}_{\text {cr }} & 2.0<\frac{\mathrm{a}}{\mathrm{d}}<3.0
\end{array}
$$

Also, they recommended that for a/d higher or equal 3.0, the ultimate concrete shear strength $\mathrm{v}_{\mathrm{c}}$ can be taken equal to cracking shear strength with small error having a maximum value of $9.0 \%$.

$$
\mathrm{q}_{\mathrm{c}}=\mathrm{q}_{\mathrm{cr}} \quad \text { for } \quad \frac{\mathrm{a}}{\mathrm{d}} \geq 3.0
$$

For the purpose of estimating the shear strength of reinforced concrete tee beams made from high strength concrete twenty six beams were analyzed under two point static loading, four of them have compressive ranged from 25 to 65 MPA while the remaining twenty two beams have $80 \mathrm{MPa}$ compressive strength. In this analysis the effect of flange to web width ratio of tee beams $(B / b)$, concrete compressive strength $F_{c u}$, shear span to depth ratio, percentage of longitudinal tension reinforcement $\rho$ and percentage of web reinforcement $\rho_{w}$ were considered. From the analysis a proposed equations were presented to predict the shear strength of high strength reinforced concrete tee beams. Also a comparison is made between the shear strengths calculated by available codes and equations with that calculated by the proposed equations.

\section{MODELING OF REINFORCED CONCRETE BEAMS BY USING FINITE ELEMENT ANALYSIS}

The eight-nodded solid element will be used in this study to analyze reinforced concrete beams. The stiffness characteristics of the elements can be determined using the theorem of minimum potential energy, which results in the following equation relating the element nodal forces:

$$
\{\mathrm{P}\}=[k] .\{\Delta\}
$$

Where $[\mathrm{k}]$ is the element stiffness matrix and is given by: 


$$
[\mathrm{k}]=\sum \int[\mathrm{B}]^{\mathrm{T}} \cdot[\mathrm{D}] \cdot[\mathrm{B}] \mathrm{dV}
$$

Where $[\mathrm{B}]$ is the strain matrix and [D] is the element elasticity matrix.

In the present work, the smeared crack approach with swinging crack direction associated with a maximum tensile strain criterion is used to simulate the behavior of elastic concrete element. The cracks are assumed to form when the principal strain exceeds the maximum tensile strain of concrete. The threedimensional eight-nodded isoparametric solid element shown in Fig. (1) has eight nodes located at the corners and has three degrees of freedom at each node. The linear shape functions defining the geometry and variation of displacements within the element can be given in the form:

$$
\mathrm{N}_{\mathrm{i}}=\frac{1}{8}\left(1+\mathrm{rr} \mathrm{r}_{\mathrm{i}}\right)\left(1+\mathrm{s} \quad \mathrm{s}_{\mathrm{i}}\right)\left(1+\mathrm{t} \mathrm{t}_{\mathrm{i}}\right)
$$

Where:

$\mathrm{r}, \mathrm{s}$ and $\mathrm{t}$ are the natural coordinates.

$r_{i}, s_{i}$ and $t_{i}$ are the values of natural coordinates for node (i) as shown in Fig. (1).

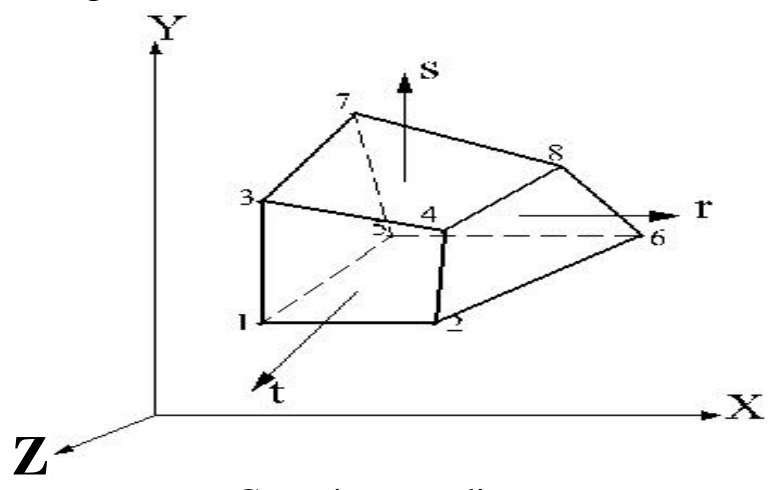

Cartesian coordinate system

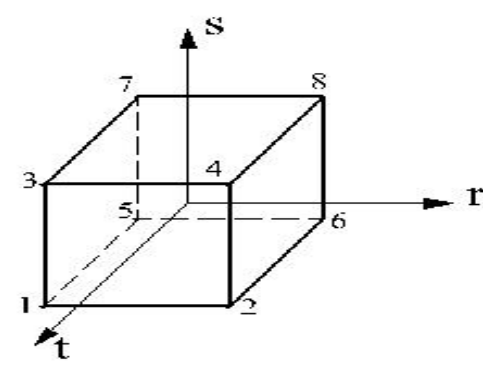

Local coordinate system

Fig.(1): Eight nodded isoparametric solid element and node numbering

The geometry of the element is described as:

$$
\left\{\begin{array}{l}
x \\
y \\
z
\end{array}\right\}=\sum_{i=1}^{8} N_{i}\left\{\begin{array}{l}
x_{i} \\
y_{i} \\
z_{i}
\end{array}\right\}
$$

where $x_{i}, y_{i}$ and $z_{i}$ are the global coordinates of node (i). The relationship between the derivatives of functions in the natural coordinates $(r, s, t)$ and the derivatives in Cartesian (global) coordinates ( $\mathrm{x}, \mathrm{y}$ z) can be established by evaluating the Jacopian [J]. The eight nodded solid element shown in Fig. (2), consists of eight nodes at its corners, each node has three displacements $\mathrm{u}, \mathrm{v}$ and $\mathrm{w}$ in directions $\mathrm{x}, \mathrm{y}$ and $\mathrm{z}$ respectively. The shape function for 
displacements at any point within the element is assumed to be linear function in $\mathrm{x}, \mathrm{y}$ and $\mathrm{z}$ and given in the form:

$$
\begin{aligned}
& \mathrm{u}=\alpha_{1}+\alpha_{2} \mathrm{x}+\alpha_{3} \mathrm{y}+\alpha_{4} \mathrm{z}+\alpha_{5} \mathrm{xy}+\alpha_{6} \mathrm{y} \mathrm{z}+\alpha_{7} \mathrm{z} \mathrm{x}+\alpha_{8} \mathrm{x} \mathrm{yz} \\
& \mathrm{v}=\alpha_{9}+\alpha_{10} \mathrm{x}+\alpha_{11} \mathrm{y}+\alpha_{12} \mathrm{z}+\alpha_{13} \mathrm{x} \mathrm{y}+\alpha_{14} \mathrm{y} \mathrm{z}+\alpha_{15} \mathrm{z} \mathrm{x}+\alpha_{16} \mathrm{x} \mathrm{y} \mathrm{z} \\
& \mathrm{w}=\alpha_{17}+\alpha_{18} \mathrm{x}+\alpha_{19} \mathrm{y}+\alpha_{20} \mathrm{z}+\alpha_{21} \mathrm{x} \mathrm{y}+\alpha_{22} \mathrm{yz}+\alpha_{23} \mathrm{zx}+\alpha_{24} \mathrm{xyz}
\end{aligned}
$$

Where $\mathrm{x}, \mathrm{y}$ and $\mathrm{z}$ are the co-ordinates of the point within the element, and $\alpha_{1}$, $\alpha_{2} \ldots \alpha_{24}$ are some factors. Assuming that nodal displacements are known and defined by the following vector $\{\delta\}$ where:

$\{\delta\}=\left\{\mathrm{u}_{1}, \mathrm{v}_{1}, \mathrm{w}_{1}, \mathrm{u}_{2}, \mathrm{v}_{2}, \mathrm{w}_{2}, \mathrm{u}_{3}, \mathrm{v}_{3}, \mathrm{w}_{3}, \mathrm{u}_{4}, \mathrm{v}_{4}, \mathrm{w}_{4}, \mathrm{u}_{5}, \mathrm{v}_{5}, \mathrm{w}_{5}, \mathrm{u}_{6}, \mathrm{v}_{6}, \mathrm{w}_{6}, \mathrm{u}, \mathrm{v}_{7}, \mathrm{w}_{7}\right.$, $\left.\mathrm{u}_{8}, \mathrm{v}_{8}, \mathrm{w}_{8}\right\}^{\mathrm{T}}$

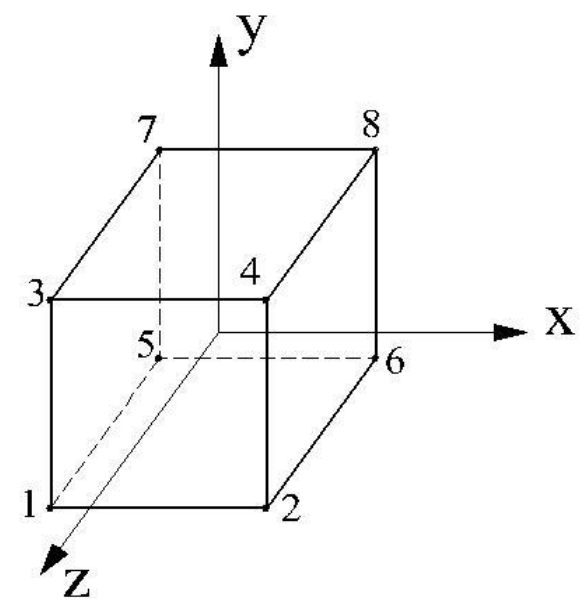

Fig. (2): 8- solid element and node numbering

And substituting in Eqn. (20) for the element nodal point, it can be obtained that:

$$
\{\delta\}=[\mathrm{A}] .\{\alpha\}
$$

Where, [A] is a matrix of size $24 \times 24$ representing the coefficients resulting from the substitution of coordinates $\mathrm{x}, \mathrm{y}$ and $\mathrm{z}$ for the different nodal points of the element in Eqn. (20), $\{\alpha\}$ is an unknown vector can be determined from the relation

$$
\{\alpha\}=[\mathrm{A}]^{-1} \cdot\{\delta\}
$$

Then, the strain at any point in the element can be given as a function of the nodal displacements, $\{\delta\}$ as follows: 


$$
\varepsilon=[H] .\{\alpha\}=[\mathrm{H}] \cdot\left[\mathrm{A}^{-1}\right] .\{\delta\}=[\mathrm{B}] .\{\delta\}
$$

Therefore $[\mathrm{B}]$ is a matrix of $6 \times 24$ relating the strain vector $\{\boldsymbol{\varepsilon}\}$ at any point within the element to the nodal displacement vector $\{\delta\}$, using Castigliano's first theorem, the element stiffness matrix $[\mathrm{K}]$ is defined for elastic isotropic element in three dimensions as:

$$
[K]=\int_{v}[B]^{\mathrm{T}} \cdot[\mathrm{D}] \cdot[\mathrm{B}] \mathrm{dv}=\left[\mathrm{A}^{-1}\right]^{\mathrm{T}} \int_{-\mathrm{c}-\mathrm{b}-\mathrm{a}}^{\mathrm{b}} \int^{\mathrm{a}} \int^{\mathrm{a}}[\mathrm{H}]^{\mathrm{T}} \cdot[\mathrm{D}] \cdot[\mathrm{H}] \mathrm{dx} \mathrm{dy} \mathrm{dz} \cdot\left[\mathrm{A}^{-1}\right]
$$

Where $2 \mathrm{a}, 2 \mathrm{~b}$ and $2 \mathrm{c}$ are the dimensions of the element in $\mathrm{x}, \mathrm{y}$ and $\mathrm{z}$ directions respectively. The derivation of the stiffness matrix is the same for either cracked or uncracked element, the only difference between the two cases are the choosing of the elasticity matrix [D]. For the cracked element either the secant stiffness matrix or the tangential stiffness matrix is used, where the secant stiffness matrix is given in the form:

$$
\left[\mathrm{K}_{\mathrm{s}}\right]=\left[\mathrm{A}^{-1}\right]^{\mathrm{T}} \int_{-\mathrm{c}-\mathrm{b}-\mathrm{a}}^{\mathrm{b}} \int_{0}^{\mathrm{a}}[\mathrm{H}]^{\mathrm{T}} \cdot\left[\mathrm{D}_{\mathrm{s}}\right] \cdot[\mathrm{H}] \mathrm{dx} \mathrm{dy} \mathrm{dz} \cdot\left[\mathrm{A}^{-1}\right]
$$

and the tangential stiffness matrix is given in form:

$$
\left[\mathrm{K}_{\mathrm{t}}\right]=\left[\mathrm{A}^{-1}\right]^{\mathrm{T}} \int_{-\mathrm{c}-\mathrm{b}-\mathrm{a}}^{\mathrm{b}} \int_{0}^{\mathrm{a}}[\mathrm{H}]^{\mathrm{T}} \cdot\left[\mathrm{D}_{\mathrm{t}}\right] \cdot[\mathrm{H}] \mathrm{dx} d \mathrm{~d} \mathrm{dz} \cdot\left[\mathrm{A}^{-1}\right]
$$

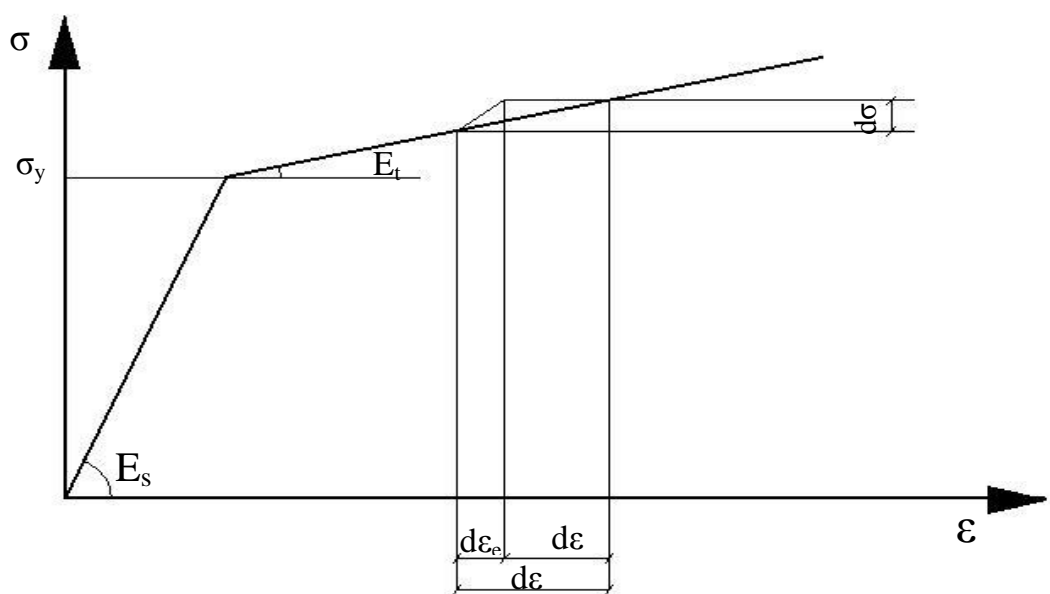

Fig. (3): Stress-strain relationship for bar member of elasto-plastic material.

\section{ELASTO-PLASTIC STIFFNESS MATRIX OF THE BAR MEMBER}

The stress- strain relationship for a bar element of elasto-plastic material is shown in Fig. (3). the bar element initially deforms elastically with axial rigidity $E_{s} A_{b}$ until the yield stress, where Es, $A_{b}$ are young's modules of elasticity of steel and the cross sectional area of the bar. By increasing the load 
further, the material is assumed to exhibit linear strain-hardening characteristics by the tangential modules $\mathrm{E}_{\mathrm{t}}$. At some stage after initial yielding, consider a further load application resulting in an incremental increase of normal force accompanied by a change of axial strain $d \varepsilon$. Assuming that the axial strain $d \varepsilon$ can be separated into elastic and plastic components, so that

$$
\mathrm{d} \varepsilon=\mathrm{d} \varepsilon_{\mathrm{e}}+\mathrm{d} \varepsilon_{\mathrm{p}}
$$

The strain hardening parameter $\mathrm{h}$ is defined as:

$$
\mathrm{h}=\frac{\mathrm{d} \sigma}{\mathrm{d} \varepsilon_{\mathrm{p}}}=\frac{\mathrm{d} \sigma}{\mathrm{d} \varepsilon-\mathrm{d} \varepsilon_{\mathrm{e}}}=\frac{\mathrm{E}_{\mathrm{t}}}{1-\mathrm{E}_{\mathrm{t}} / \varepsilon}
$$

And the tangent modulus $\mathrm{E}_{\mathrm{t}}$ can be given as:

$$
\mathrm{E}_{\mathrm{t}}=\mathrm{E}_{\mathrm{s}}\left(1-\frac{\mathrm{E}_{\mathrm{s}}}{\mathrm{E}_{\mathrm{s}}+\mathrm{h}}\right)
$$

The bar stiffness matrix can be written in the finite element form as:

$$
\left[\mathrm{K}_{\mathrm{e}}\right]=\int_{\mathrm{v}}[\mathrm{B}]^{\mathrm{T}}[\mathrm{D}][\mathrm{B}] \mathrm{dv}=\mathrm{A}_{\mathrm{b}} \int_{0}^{\ell}[\mathrm{B}]^{\mathrm{T}}[\mathrm{D}][\mathrm{B}] \mathrm{dx}
$$

Where for linear axial displacement, $\quad[\mathrm{D}]=\mathrm{E}_{\mathrm{s}}$ And: $[\mathrm{B}]=\left[\begin{array}{cc}-\frac{1}{\ell} & \frac{1}{\ell}\end{array}\right]$ Where $\ell$ is the length of the bar.

\section{MECHANICAL BEHAVIOR OF CONCRETE UNDER STATIC LOADING}

For concrete in uni-axial compression, the following equation of Nilson [5] is used:

$$
f=\frac{E_{\varepsilon}}{1+\left(R+R_{E}-2\right) \frac{\varepsilon}{\varepsilon_{o}}-(2 R-1)\left(\frac{\varepsilon}{\varepsilon_{o}}\right)^{2}+R\left(\frac{\varepsilon}{\varepsilon_{o}}\right)^{3}}
$$

Where: $\mathrm{f}=$ stress at strain e,

$\mathrm{f}_{\mathrm{f}}=$ failure stress at failure strain $\mathrm{e}_{\mathrm{f}}$

$\varepsilon_{0}=$ strain corresponding to maximum stress $\mathrm{f}_{\mathrm{o}}$,

$\mathrm{E}=$ the initial tangent modulus,

$$
\begin{aligned}
\mathrm{E}_{\mathrm{e}} & =\text { the secant modulus }=\frac{f_{o}}{\varepsilon_{o}}, \mathrm{R}_{\mathrm{E}}=\frac{\mathrm{E}}{\mathrm{E}_{\mathrm{s}}}, \mathrm{R}_{\mathrm{f}}=\frac{\mathrm{f}_{\mathrm{o}}}{\mathrm{f}}, R_{e}=\frac{\varepsilon_{r}}{\varepsilon_{f}} \text { and } \\
\mathrm{R} & =\frac{\mathrm{R}_{\mathrm{E}}\left(\mathrm{R}_{\mathrm{f}}-1\right)}{\left(\mathrm{R}_{\mathrm{e}}-1\right)^{2}}-\frac{1}{\mathrm{R}_{\mathrm{e}}}
\end{aligned}
$$

Equation (31) is plotted in Fig. (4). For particular concrete, is differentiated with respect to strain to obtain the instantaneous tangent modulus as a function 
of concrete strain. For concrete in uni-axial tension, it assumed that linear behavior is obtained up to failure.

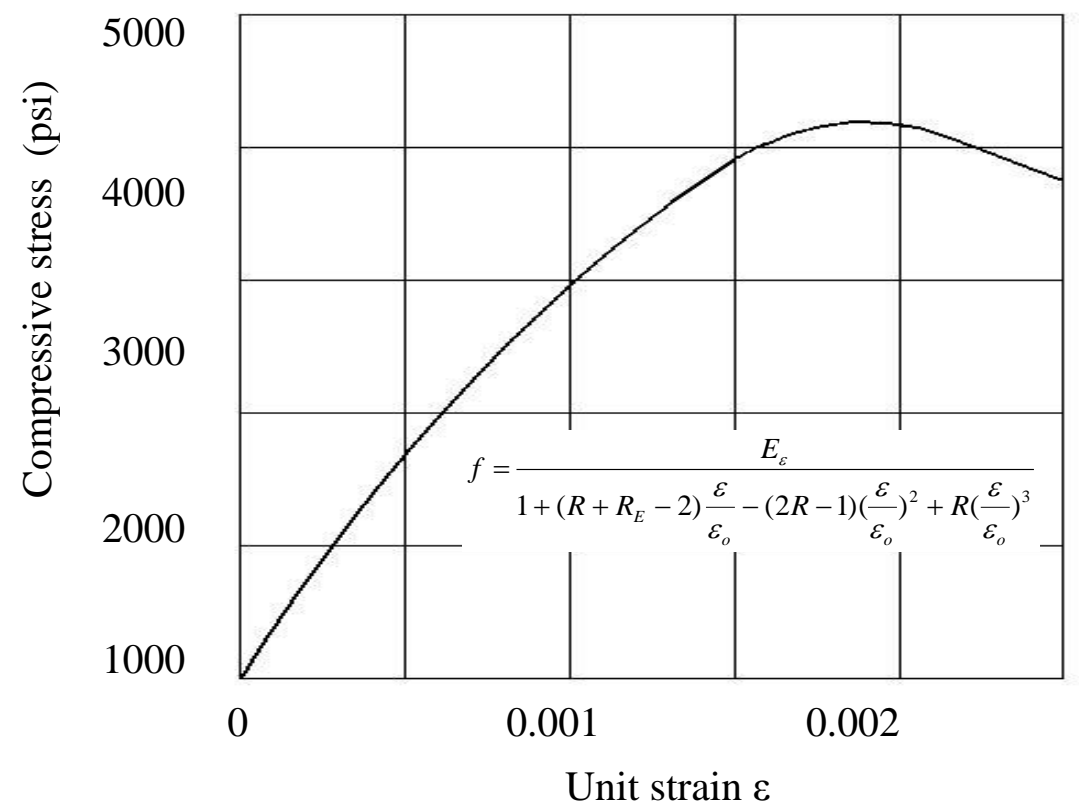

Fig. (4): compressive stress-strain curve for concrete

Vecchio [6] developed a nonlinear finite element procedure to predict the response of reinforced concrete membrane elements based on a secant stiffness formulation. The stress in the concrete and reinforcement are determined from the strains according to the modified compression field theory. The principal compressive stress in the concrete $\mathrm{F}_{\mathrm{c}}$ is:

$$
\mathrm{F}_{\mathrm{c}}=\mathrm{F}_{\mathrm{c} \max } \times\left|2\left(\frac{\varepsilon}{\varepsilon_{\mathrm{o}}}\right)-\left(\frac{\varepsilon}{\varepsilon_{\mathrm{o}}}\right)^{2}\right|
$$

Where: $\quad \mathrm{F}_{\mathrm{c} \max }=\frac{\mathrm{F}_{\mathrm{c} 28}}{0.8-0.34 \varepsilon / \varepsilon_{\mathrm{o}}}$

\section{STRESS-STRAIN CURVE FOR LOW, NORMAL AND HIGH STRENGTH CONCRETE:}

Fig.(5) illustrate the stress-strain relationship for the homogeneous material under tension. The behavior of concrete is completely different from that of the brittle homogeneous material; the residual strain of the concrete is due to cracked formation. The stress-strain curve for concrete of low, normal and high strength have the same shape. In Fig. (6) a high strength concrete behaves in a linear fashion to a relatively higher level than the low strength concrete. This 
because the high quality concrete has no micro cracks up to a close value to the maximum stress. However, the low quality concrete is subjected to micro crack formation even at low stress level, [7] and [8].

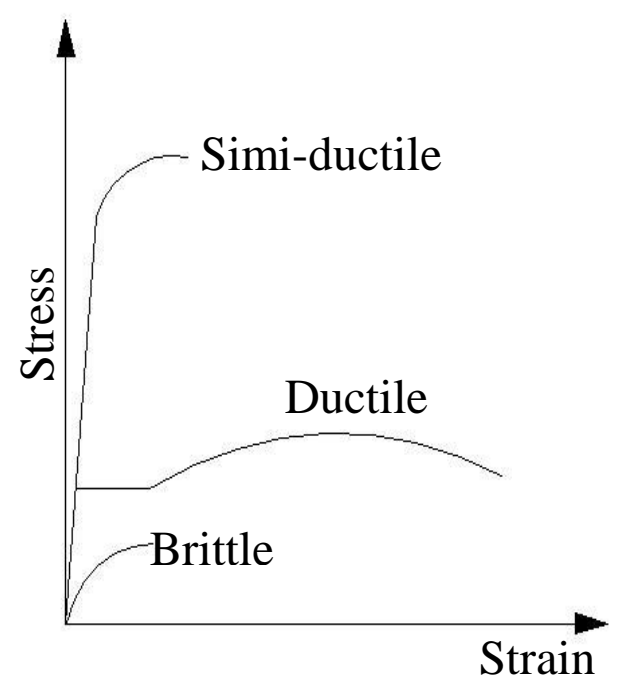

Fig. (5): Typical stress-strain curve for homogeneous materials,[4].

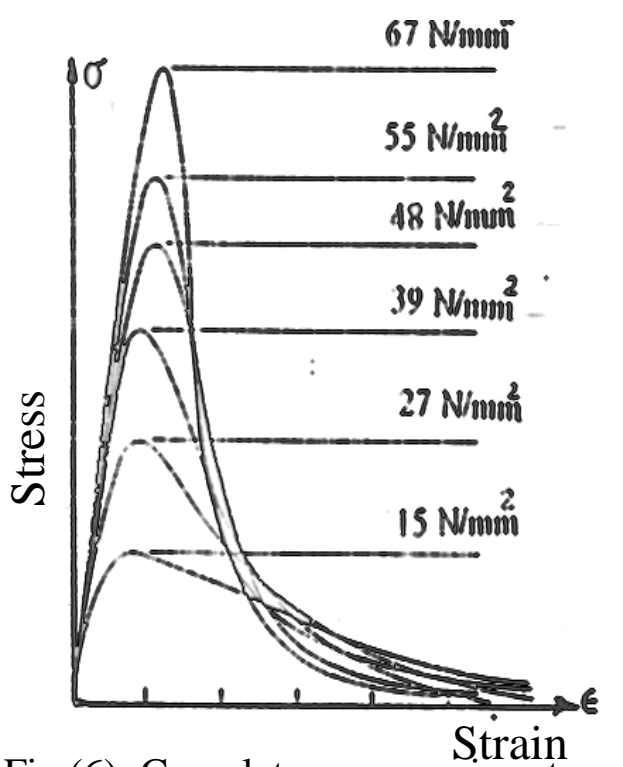

Fig.(6): Complete compressive stress strain curve of concrete.

\section{VERIFICATION OF THE USED COMPUTER PROGRAM}

The prepared program allows the use of only the 8-nodded solid isoparametric element and one bar element to simulate the concrete and the reinforced steel respectively. The accuracy of the used computer program is checked by comparing the results of shear strength of the beams that tested experimentally by M. Hashem, [9] and Khaled et-al [4], and the same beams that analyzed theoretically by using (R.C.32) program,[2]. Table (1) presents the comparison between the shear strength calculated by the used program and the experimental results of M. Hashem, [9] and Khaled et-al [4]. 
Table (1) Comparison between the experimental results and the computer program results

\begin{tabular}{|c|c|c|c|c|c|c|c|c|}
\hline \multirow[t]{2}{*}{ Ref. } & \multirow{2}{*}{$\begin{array}{c}\text { Beam } \\
\text { No. }\end{array}$} & \multirow[t]{2}{*}{$\mathrm{a} / \mathrm{d}$} & \multirow[t]{2}{*}{$\mathrm{B} / \mathrm{b}$} & \multirow{2}{*}{$\begin{array}{l}\text { Span } \\
\mathrm{Cm} .\end{array}$} & \multirow{2}{*}{$\begin{array}{c}\mathrm{F}_{\mathrm{c}} \\
\mathrm{MPa}\end{array}$} & \multicolumn{2}{|c|}{ Ultimate shear (ton) } & \multirow{2}{*}{$\begin{array}{l}\Delta \\
\%\end{array}$} \\
\hline & & & & & & Exp. & Theo. & \\
\hline \multirow{4}{*}{ [9] } & B1 & 2 & 1 & 105 & 20 & 23.85 & 25.79 & -8.13 \\
\hline & B3 & 2 & 2 & 105 & 20 & 31.20 & 33.79 & -8.30 \\
\hline & C1 & 3 & 1 & 160 & 20 & 18.08 & 18.72 & -3.54 \\
\hline & C3 & 3 & 2.75 & 140 & 20 & 28.70 & 30.79 & -7.28 \\
\hline \multirow{4}{*}{ [4] } & A5 & 2 & 1 & 151 & 32.5 & 23.89 & 22.76 & 4.96 \\
\hline & A3 & 2 & 1 & 151 & 80 & 32.80 & 31.40 & 4.27 \\
\hline & E1 & 2 & 3 & 151 & 32.5 & 30.40 & 29.00 & 4.61 \\
\hline & E2 & 2 & 3 & 151 & 85 & 43.90 & 42.00 & 4.33 \\
\hline
\end{tabular}

From this table it is clear that the accuracy and efficiency of the computer program was accepted.

\section{ANALYZED PROGRAM}

Twenty-six reinforced concrete beams were analyzed by using (R.C.32) program,[2], twenty-two of them have high compressive strength of $80 \mathrm{MPa}$ and the remaining four have 25,35,50 and $65 \mathrm{MPa}$ compressive strength. These beams were arranged in four groups (A, B, C, and D). Complete details for the tested beams are presented in Table 1 and Fig. 7 shows the details of the analyzed beams. The web reinforcement ratio was changed through changing the diameters of the stirrups and the spacing between stirrups was kept constant equal to $20 \mathrm{~cm}$. The used stirrups bars are 6,8 and $10 \mathrm{~mm}$ diameter. The web reinforcement ratios considered in this study are changed from 0 to $0.524 \%$. All web reinforcements were mild steel of grade (St. 24/35), with $240 \mathrm{~N} / \mathrm{mm}^{2}$ yield strength and $360 \mathrm{~N} / \mathrm{mm}^{2}$ ultimate strength. The strain of concrete at the ultimate stress is assumed equals to 0.003. The effect of longitudinal reinforcement ratios were studied through changing the diameter of tension reinforcement bar as: $3 \varnothing 24,3 \varnothing 20,3 \varnothing 16$ and $3 \varnothing 12$. The beams were reinforced with percentage of tension reinforcement $(\rho)$ as $2.92 \%, 2.04 \%, 1.30$ $\%$ and $0.73 \%$. All the longitudinal reinforcements were high tensile steel of grade $(360 / 520)$, with $360 \mathrm{~N} / \mathrm{mm}^{2}$ yield strength and $520 \mathrm{~N} / \mathrm{mm}^{2}$ ultimate strength. 
Table (2) Details of the analyzed beams

\begin{tabular}{|c|c|c|c|c|c|c|c|}
\hline Group & Beam & $\mathrm{a} / \mathrm{d}$ & $\mathrm{B} / \mathrm{b}$ & $\mathrm{L}_{\mathrm{e}}(\mathrm{cm})$ & Stirrups & Main steel & $\mathrm{F}_{\mathrm{c} 28}(\mathrm{MPa})$ \\
\hline \multirow{8}{*}{ A } & $\mathrm{A}_{1-1}$ & 1 & 3 & 93 & $5 \varnothing 8$ & $3 \Phi 24$ & 800 \\
\hline & $\mathrm{A}_{1-2}$ & 2 & 3 & 186 & $5 \varnothing 8$ & $3 \Phi 24$ & 800 \\
\hline & $\mathrm{A}_{1-3}$ & 3 & 3 & 279 & $5 \varnothing 8$ & $3 \Phi 24$ & 800 \\
\hline & $\mathrm{A}_{1-4}$ & 4 & 3 & 372 & $5 \varnothing 8$ & $3 \Phi 24$ & 800 \\
\hline & A2-2 & 2 & 3 & 186 & $5 \varnothing 8$ & $3 \Phi 24$ & 250 \\
\hline & $\mathrm{A}_{3-1}$ & 2 & 3 & 186 & $5 \varnothing 8$ & $3 \Phi 24$ & 350 \\
\hline & $\mathrm{A}_{3-2}$ & 2 & 3 & 186 & $5 \varnothing 8$ & $3 \Phi 24$ & 500 \\
\hline & $A_{3-3}$ & 2 & 3 & 186 & $5 \varnothing 8$ & $3 \Phi 24$ & 650 \\
\hline \multirow{6}{*}{ B } & $\mathrm{B}_{1-1}$ & 2 & 1 & 186 & $5 \varnothing 8$ & $3 \Phi 24$ & 800 \\
\hline & $\mathrm{B}_{1-2}$ & 2 & 2 & 186 & $5 \varnothing 8$ & $3 \Phi 24$ & 800 \\
\hline & $\mathrm{B}_{1-3}$ & 2 & 4 & 186 & $5 \varnothing 8$ & $3 \Phi 24$ & 800 \\
\hline & $\mathrm{B}_{1-4}$ & 4 & 1 & 372 & $5 \varnothing 8$ & $3 \Phi 24$ & 800 \\
\hline & $\mathrm{B}_{1-5}$ & 4 & 2 & 372 & $5 \varnothing 8$ & $3 \Phi 24$ & 800 \\
\hline & $\mathrm{B}_{1-6}$ & 4 & 4 & 372 & $5 \varnothing 8$ & $3 \Phi 24$ & 800 \\
\hline \multirow{6}{*}{$\mathrm{C}$} & $\mathrm{C}_{1-1}$ & 2 & 3 & 186 & $\mathrm{NO}$ & $3 \Phi 24$ & 800 \\
\hline & $\mathrm{C}_{1-2}$ & 2 & 3 & 186 & $5 \varnothing 6$ & $3 \Phi 24$ & 800 \\
\hline & $\mathrm{C}_{1-3}$ & 2 & 3 & 186 & $5 \varnothing 10$ & $3 \Phi 24$ & 800 \\
\hline & $\mathrm{C}_{1-4}$ & 4 & 3 & 372 & $\mathrm{NO}$ & $3 \Phi 24$ & 800 \\
\hline & $\mathrm{C}_{1-5}$ & 4 & 3 & 372 & $5 \varnothing 6$ & $3 \Phi 24$ & 800 \\
\hline & $\mathrm{C}_{1-6}$ & 4 & 3 & 372 & $5 \varnothing 10$ & $3 \Phi 24$ & 800 \\
\hline \multirow{6}{*}{$\mathrm{D}$} & $\mathrm{D}_{1-1}$ & 2 & 3 & 186 & $5 \varnothing 8$ & $3 \Phi 20$ & 800 \\
\hline & $D_{1-2}$ & 2 & 3 & 186 & $5 \varnothing 8$ & $3 \Phi 16$ & 800 \\
\hline & $D_{1-3}$ & 2 & 3 & 186 & $5 \varnothing 8$ & $3 \Phi 12$ & 800 \\
\hline & $\mathrm{D}_{1-4}$ & 4 & 3 & 372 & $5 \varnothing 8$ & $3 \Phi 20$ & 800 \\
\hline & $D_{1-5}$ & 4 & 3 & 372 & $5 \varnothing 8$ & $3 \Phi 16$ & 800 \\
\hline & $D_{1-6}$ & 4 & 3 & 372 & $5 \varnothing 8$ & $3 \Phi 12$ & 800 \\
\hline
\end{tabular}


The modulus of elasticity of concrete depends on its compressive strength, and its value is calculated by using the Egyptian code ECCS203-2001, [1], for normal grade of compressive strength concrete of $25 \mathrm{~N} / \mathrm{mm}^{2}$ and $35 \mathrm{~N} / \mathrm{mm}^{2}$. While for high compressive strength concrete 50,65 and $80 \mathrm{~N} / \mathrm{mm}^{2}$, the modulus of elasticity is calculated using the following equation:

$$
\mathrm{Ec}=3320 \sqrt{\mathrm{F}_{\mathrm{c} 28}}+6900 \quad \mathrm{~N} / \mathrm{mm}^{2} .
$$

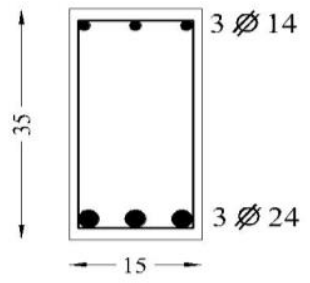

a) Rectangular cross section $\mathrm{B} / \mathrm{b}=1$

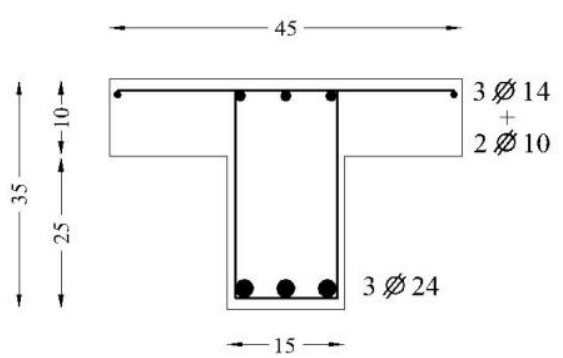

c) $\mathrm{T}-$ section with $\mathrm{B} / \mathrm{b}=3$

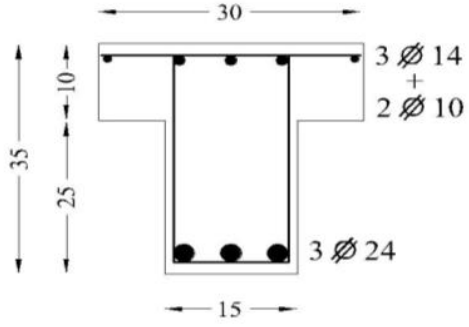

b) $\mathrm{T}-$ section with $\mathrm{B} / \mathrm{b}=2$

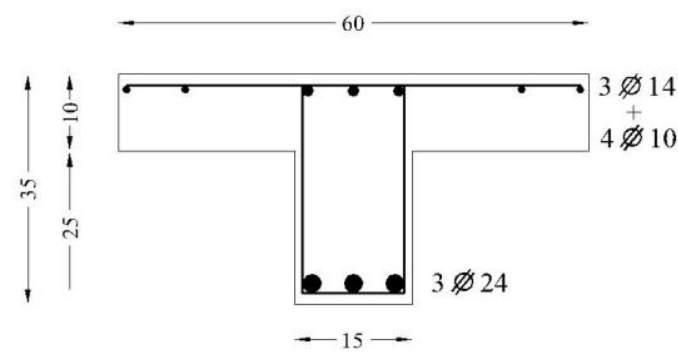

d) $\mathrm{T}-$ section with $\mathrm{B} / \mathrm{b}=4$

Fig. (7-b): Cross sections of the analyzed beams.

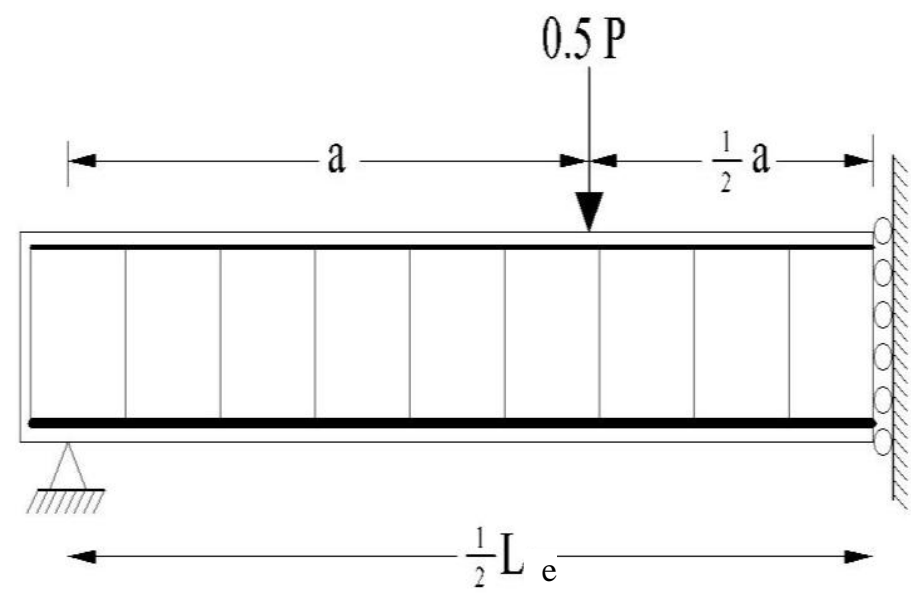

Fig. (8): Details of the analyzed beams. 


\section{RESULTS AND DISCUSSION}

\section{PATTERNS OF CRACKS AND MODES OF FAILURE}

For both short and slender beams, firstly in beams having rectangular cross section there is a diagonal crack was formed clearly along the total depth of the beam, but in T-section beams the diagonal crack formed along the beam web only and don't subsist to the flange. The width and the length of the diagonal crack depend on the width of the flange as shown in Fig (9). The width and the length of the diagonal crack depend on the width of the flange. The width and the length of the diagonal crack depends on the width of the flange, also another vertical cracks is formed at the midspan of slender beams only, as shown in Fig (9).

Presence of stirrups has a considerable effect on pattern of cracks and the final mode of failure. The importance of stirrups already appeared when the first inclined crack occurred, that as the crack opens, the stirrups help to contain the crack, limiting its propagation and keeping its width smaller than beams without stirrups. Another secondary diagonal cracks formed approximately parallel to the direction of the first inclined crack. The amount of longitudinal steel ratio has slight effect on final mode of failure as the longitudinal steel ratio increases, the number of cracks decreases and hence affects the inclination of the main crack. The concrete compressive strength has a considerable effect on pattern of cracks, especially for beams having higher longitudinal steel ratios. For beams made from high-strength concrete, several flexural cracks developed than that for beams made from normal strength concrete. The inclination of the main crack does not affect by the concrete strength. Presence of beam flange has a considerable effect on pattern of cracks and the final mode of failure, especially for beams made from high-strength concrete and having small values of a/d ratio. 


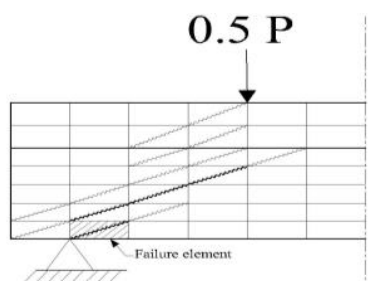

Pattern of cracks of beam $\mathrm{A}_{1-1}$

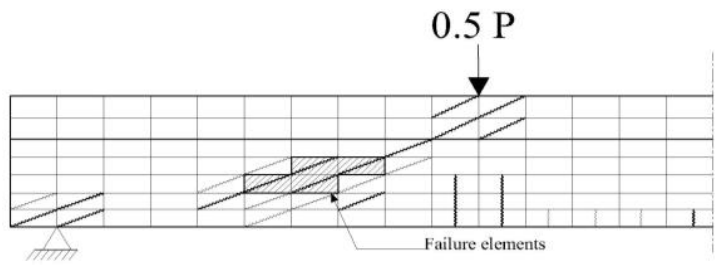

Pattern of cracks of beam $\mathrm{A}_{1-3}$

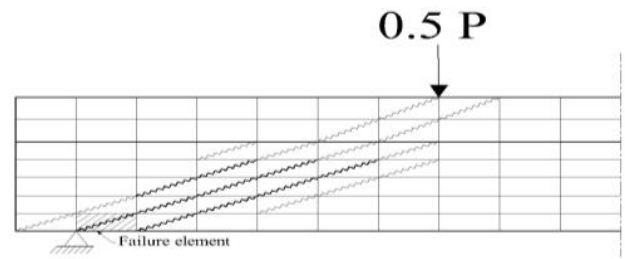

Pattern of cracks of beam $\mathrm{A}_{2-2}$

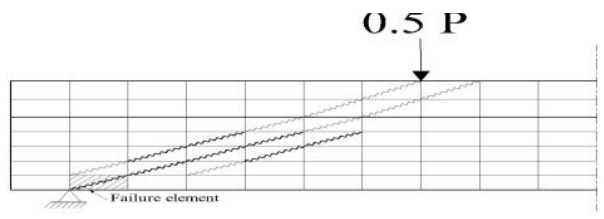

Pattern of cracks of beam $\mathrm{A}_{3-2}$

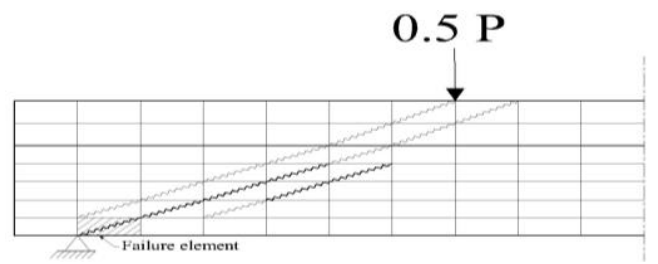

Pattern of cracks of beam $\mathrm{A}_{1-2}$

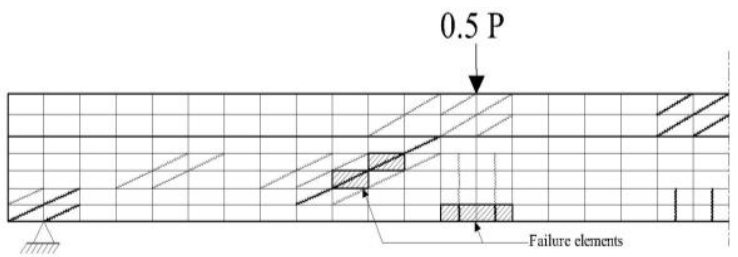

Pattern of cracks of beam $\mathrm{A}_{1-4}$

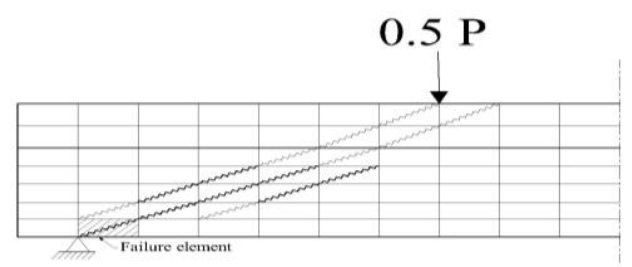

Pattern of cracks of beam $\mathrm{A}_{3-1}$

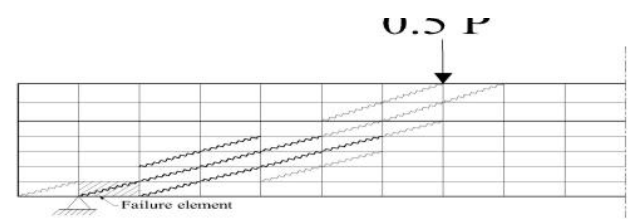

Pattern of cracks of beam $\mathrm{A}_{3-3}$

Fig.(9): Pattern of cracks of beams of group A.

\section{CRACKING SHEAR STRENGTH}

The cracking shear strength is defined as the shear stress at the time when the critical diagonal crack formed any where along the span. The value of cracking shear strength is expressed in terms of nominal cracking shear stress $q_{c r}$, which given by as following:

$$
\mathrm{q}_{\mathrm{cr}}=\frac{\mathrm{Q}_{\mathrm{cr}}}{\mathrm{b} \cdot \mathrm{d}}
$$

The values of the evaluated cracking shear strength for the analyzed beams are given in table (3). Investigation of table (3) show that, beams having small values of a/d ratios having higher values of cracking shear strength than that 
having higher values of a/d ratios, this result agree with [4], [9]. For short beams the a/d ratios is more effective in cracking shear strength than other variables. The cracking shear strength decreases as a/d ratio increases. This is because large values of a/d means high values of bending moment in shear span, thus the depth of penetration of flexural cracks increases, and hence the flexural stresses near the crack tip increase. By increasing a/d, the probability grows that a flexural crack will develop clearly. The cracking shear strength of beams having a/d ratios equals to 1.00 is 1.91 times of the cracking shear strength of beams having a/d $=4.0$.

The results show that, beams having high flange to web width ratio, have higher values of cracking shear strength than beams having low $B / b$ ratios or beams having rectangular cross section. The flange to web width ratio have considerable effect on the cracking shear strength of slender beams and a slight effect on cracking shear strength of short beams.

Generally, increasing tension steel ratio increases cracking shear strength. It is clear that, for short high strength concrete T-beams, increasing tension steel ratio from $0.73 \%$ to $2.92 \%$ increases the cracking shear strength by $15.0 \%$. Also, for slender high strength T-beams, increasing of tension steel ratio from $0.73 \%$ to $2.92 \%$ increases the cracking shear strength by $5.10 \%$. The longitudinal steel ratio has a pronounced effect on the basic shear transfer mechanisms.

As the concrete compressive strength increases, the cracking shear strength of the analyzed beams increases. Increase of concrete compressive strength for Tbeams having $\mathrm{B} / \mathrm{b}$ equals to 3.00 from 25 to $80 \mathrm{MPa}$, increasing the cracking shear strength by $56.51 \%$ for a/d ratio equals to 2.0. Concrete compressive strength is more effective for slender beams than that short beams. The cracking shear strength decreases slightly as a/d increases from 1.00 to 3.00, and increased sharply as a/d increased from 3.00 to 4.00 . The increas in cracking shear strength of slender T-beams made from high strength concrete, $(\mathrm{a} / \mathrm{d}=4$, $F_{c 28}=80$ ) was the highest one due to the fact that, the area of compression zone was higher because the high strength concrete beams was under reinforced sections. From table (3), it appears that the stirrups have no effect on cracking shear strength for high strength concrete for both slender and short beams. 
Table (3): Cracking and ultimate shear strength of analyzed beams

\begin{tabular}{|c|c|c|c|c|c|c|c|c|}
\hline Beam & $\mathrm{a} / \mathrm{d}$ & $\mathrm{B} / \mathrm{b}$ & $\rho \%$ & $\rho_{w} . F_{y w}$ & $\begin{array}{c}\mathrm{F}_{\mathrm{c} 28} \\
\mathrm{MPa}\end{array}$ & $\begin{array}{c}\mathrm{q}_{\mathrm{cr}} \\
\mathrm{kg} / \mathrm{cm}^{2}\end{array}$ & $\begin{array}{c}\mathrm{q}_{\mathrm{u}} \\
\mathrm{kg} / \mathrm{cm}^{2}\end{array}$ & $\begin{array}{c}\text { Mode of } \\
\text { failure }\end{array}$ \\
\hline $\mathrm{A}_{1-1}$ & 1 & 3 & 2.92 & 8.04 & 80 & 9.89 & 41.6 & D.T \\
\hline $\mathrm{A}_{1-2}$ & 2 & 3 & 2.92 & 8.04 & 80 & 8.17 & 38.36 & D.T \\
\hline $\mathrm{A}_{1-3}$ & 3 & 3 & 2.92 & 8.04 & 80 & 6.37 & 28.42 & S.C \\
\hline $\mathrm{A}_{1-4}$ & 4 & 3 & 2.92 & 8.04 & 80 & 5.18 & 21.35 & F.T \\
\hline $\mathrm{A}_{2-2}$ & 2 & 3 & 2.92 & 8.04 & 25 & 5.02 & 25.67 & D.T \\
\hline $\mathrm{A}_{3-1}$ & 2 & 3 & 2.92 & 8.04 & 35 & 6.9 & 29.00 & D.T \\
\hline $\mathrm{A}_{3-2}$ & 2 & 3 & 2.92 & 8.04 & 50 & 7.6 & 31.5 & D.T \\
\hline $\mathrm{A}_{3-3}$ & 2 & 3 & 2.92 & 8.04 & 65 & 7.8 & 34.2 & D.T \\
\hline $\mathrm{B}_{1-1}$ & 2 & 1 & 2.92 & 8.04 & 80 & 7.16 & 30.53 & S.C \\
\hline $\mathrm{B}_{1-2}$ & 2 & 2 & 2.92 & 8.04 & 80 & 7.56 & 37.62 & S.C \\
\hline $\mathrm{B}_{1-3}$ & 2 & 4 & 2.92 & 8.04 & 80 & 8.45 & 41.26 & S.C \\
\hline $\mathrm{B}_{1-4}$ & 4 & 1 & 2.92 & 8.04 & 80 & 3.13 & 17.60 & S.C \\
\hline $\mathrm{B}_{1-5}$ & 4 & 2 & 2.92 & 8.04 & 80 & 4.10 & 20.70 & F.T \\
\hline $\mathrm{B}_{1-6}$ & 4 & 4 & 2.92 & 8.04 & 80 & 5.43 & 22.00 & F.t \\
\hline $\mathrm{C}_{1-1}$ & 2 & 3 & 2.92 & 0.00 & 80 & 8.10 & 31.40 & S.C \\
\hline $\mathrm{C}_{1-2}$ & 2 & 3 & 2.92 & 4.51 & 80 & 8.16 & 37.16 & S.C \\
\hline $\mathrm{C}_{1-3}$ & 2 & 3 & 2.92 & 12.55 & 80 & 8.16 & 39.20 & S.C \\
\hline $\mathrm{C}_{1-4}$ & 4 & 3 & 2.92 & 0.00 & 80 & 5.07 & 19.24 & S.C \\
\hline $\mathrm{C}_{1-5}$ & 4 & 3 & 2.92 & 4.51 & 80 & 5.13 & 20.51 & F.T \\
\hline $\mathrm{C}_{1-6}$ & 4 & 3 & 2.92 & 12.55 & 80 & 5.22 & 21.71 & F.T \\
\hline $\mathrm{D}_{1-1}$ & 2 & 3 & 2.04 & 8.04 & 80 & 7.74 & 37.80 & S.C \\
\hline $\mathrm{D}_{1-2}$ & 2 & 3 & 1.30 & 8.04 & 80 & 7.32 & 35.60 & S.C \\
\hline $\mathrm{D}_{1-3}$ & 2 & 3 & 0.73 & 8.04 & 80 & 7.10 & 35.30 & S.C \\
\hline $\mathrm{D}_{1-4}$ & 4 & 3 & 2.04 & 8.04 & 80 & 5.06 & 20.81 & S.C \\
\hline $\mathrm{D}_{1-5}$ & 4 & 3 & 1.30 & 8.04 & 80 & 4.97 & 20.33 & S.C \\
\hline $\mathrm{D}_{1-6}$ & 4 & 3 & 0.73 & 8.04 & 80 & 4.93 & 19.36 & F.T \\
\hline & & & & & & & & \\
\hline
\end{tabular}

\section{ULTIMATE SHEAR STRENGTH}

The ultimate shear strength means the maximum value of shear stress that can be sustained by the beam cross-section. The value of ultimate shear strength conventionally expressed in terms of nominal ultimate shear stress $\mathrm{v}_{\mathrm{u}}$, which is

$$
\mathrm{q}_{\mathrm{u}}=\frac{\mathrm{Q}_{\mathrm{u}}}{\mathrm{bd}}
$$

given by: 
The results of ultimate shear strength of the analyzed beams are presented in table (3). From this table it is appears that the ultimate shear strength of the analyzed beams depend on the studied variables. The ultimate shear strength decreases as a/d ratio increases high strength concrete beams. For short and deep beams, there is significant reserve strength after inclined cracking due to arch action. It is appears that, as the shear span to depth ratio increases from 1.00 to 2.00 the ultimate shear strength decreases by $7.8 \%$. The ultimate shear strength decreases by $24.14 \%$, as the shear span to depth ratio increases from 3.00 to 4.00 in high strength concrete. The ultimate shear strength of short beams, $\mathrm{a} / \mathrm{d}=1.0$, was 1.95 times the ultimate shear strength of slender beams, $\mathrm{a} / \mathrm{d}=4.0$, made from high strength concrete.

The beams having high flange to web width ratios have higher values of ultimate shear strength than beams having low ratios or beams having rectangular cross section this increases is due to shear force carried by flange area. For short beams increasing of flange to web width ratio from 1.00 to 2.00 , is increasing the ultimate shear strength by $11.25 \%$. Also, for slender beams increasing of flange to web width ratio from 1.00 to 2.00 is increasing of the ultimate shear strength $17.6 \%$.

For short beams as flange to web width ratio increases from 3.00 to 4.00 , the ultimate shear strength increases by $7.6 \%$. Also, for slender beams as flange to web width ratio increases from 3.00 to 4.00 , the ultimate shear strength increases by slightly by $3.04 \%$. This leads us to conclude that, $\mathrm{B} / \mathrm{b}$ has a slight effect on ultimate shear strength for short beams. But otherwise, the flange to web width ratio, $B / b$, has a clear effect on ultimate shear strength in slender beams.

It was noticed that increasing the longitudinal steel ratio tends to increase the ultimate shear strength of the analyzed beams. For short T-beams, increasing of tension steel ratio from $0.73 \%$ to $2.92 \%$ is increasing the ultimate shear strength by $8.7 \%$ for high strength concrete T-beams. Also, for slender Tbeams, increasing of tension steel ratio from $0.73 \%$ to $2.92 \%$ increasing the ultimate shear strength by $10.28 \%$. The increasing of shear stresses due to increasing longitudinal steel ratio, because of, as the area of tension steel increases, the natural axis moves toward the steel, hence the area of compression zone increases, and then, the shear force carried by it increases.

In generally the ultimate shear strength of the analyzed beams increased as the concrete compressive strength increased. Increasing concrete compressive strength from 25 to $80 \mathrm{MPa}$, increasing the ultimate shear strength by $31.8 \%$, $49.4 \%, 61.84 \%$ and $59.3 \%$ for a/d ratios of $1.00,2.00,3.00$ and 4.00 respectively, for T-beams of $\mathrm{B} / \mathrm{b}$ equals to 3.00. Concrete compressive strength is more effective for beams having high $a / d$ ratios than that having low ratios of 
a/d. Concrete compressive strength is more effective than shear span to depth ratio in resisting shear stresses.

Investigation of table (3) show that the ultimate shear strength of beams having web reinforcement is higher than those without web reinforcement and the shear strength is increasing as the web reinforcement parameter increases. As the web reinforcement parameter increased from zero to $12.55 \mathrm{~kg} / \mathrm{cm}^{2}$, the ultimate shear strength increased by $24.84 \%$ and $12.80 \%$ for short and slender T-beams respectively. It is clearly that stirrups not only carry shear themselves but also enhance the strength of the other shear transfer mechanisms. The stirrups provide support for the longitudinal steel and prevent the bars from splitting from the surrounding concrete, at the same time, the stirrups held to contain the crack, limiting its propagation and keeping its width small. Stirrups also increase the strength of compression concrete by providing confinement. Although stirrups don't affect the diagonal cracking load, they enhance the concrete contribution by increasing the capacity of the different shear transfer mechanism.

\section{PROPOSED EQUATION FOR ESTIMATING SHEAR STRENGTH FOR R.C. T-BEAMS EQUATIONS FOR CRACKING SHEAR STRENGTH}

The examination of the cracking shear strength indicates that, the shearing stresses at cracking level depends mainly on shear span to depth ratio, $a / d$, percentage of main steel ratio, $\rho$, and flange to web width ratio, $B / b$, for a certain grade of concrete.

The obtained values of initial cracking shear stress, are statistically treated using the available data and may be best fitted and writen as the following form in S.I unites:

$$
\begin{array}{lr}
\mathrm{q}_{\mathrm{cr}}=36.18 \times \rho \times \mathrm{S}+0.715 \times \sqrt[3]{\mathrm{F}_{\mathrm{c} 28}} & \frac{\mathrm{a}}{\mathrm{d}} \leq 2 \\
\mathrm{q}_{\mathrm{cr}}=1.413 \times \sqrt{\rho} \times \mathrm{S}^{2}+0.4 \times \sqrt[3]{\mathrm{F}_{\mathrm{c} 28}} & 2<\frac{\mathrm{a}}{\mathrm{d}} \leq 4
\end{array}
$$

The values of cracking shear strength by using above equations are represented in Fig. (10), in addition to the results of cracking shear strength. 


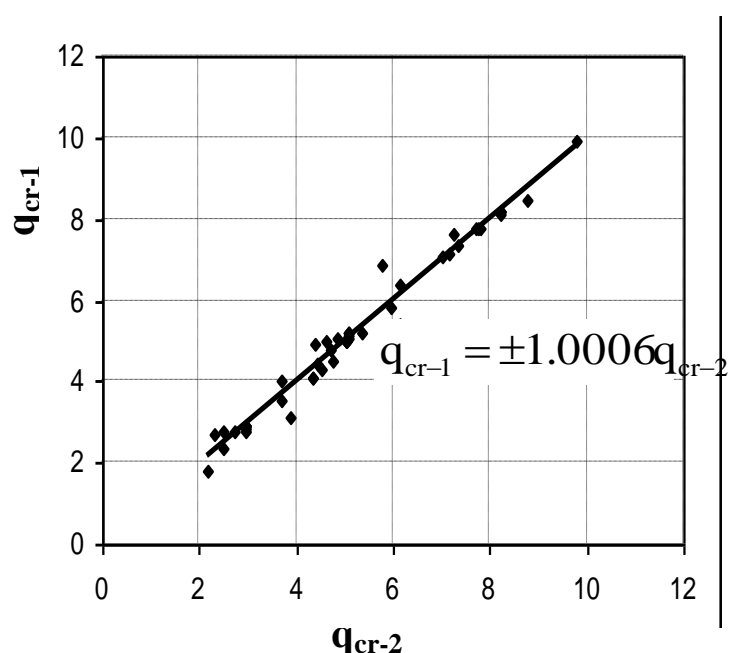

Fig. (10): The relationship between cracking values of shear strength of analyzed beams and that estimated by eans. (35) and (36).

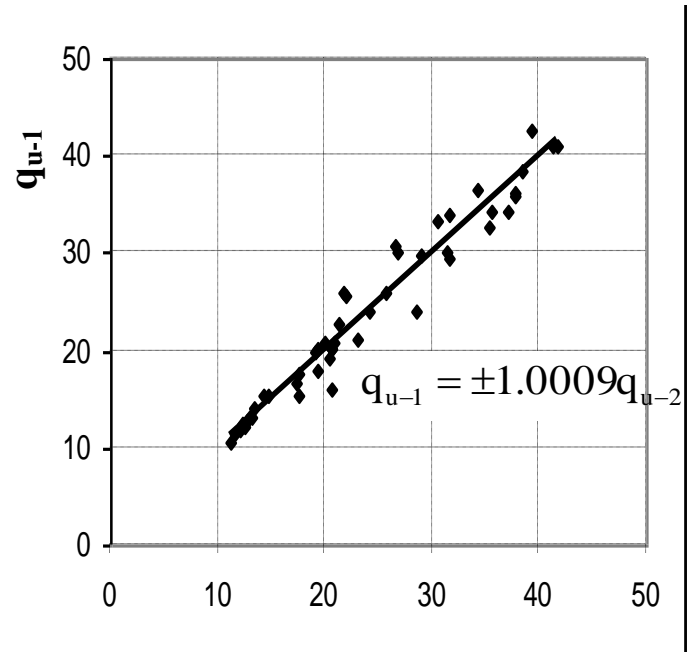

qu-2

Fig. (11): The relationship between ultimate values of shear strength of analyzed beams and that estimated by ean. (37) to (39).

\section{EQUATIONS FOR ULTIMATE SHEAR STRENGTH:}

Also, the examination of the values of ultimate shear strength of the analyzed T-beams indicates that, the ultimate shearing stresses depends mainly on web reinforcement factor, shear span to depth ratio, percentage of main steel ratio, and flange to web width ratio for certain grade of concrete. The obtained values of ultimate shear stress, are statistically treated using the available data and may be best fitted and written as the following form:

\section{FOR BEAMS WITH WEB REINFORCEMENT:}

$$
\begin{array}{lr}
q_{u}=q_{c r}+2.08 \times\left(100 \rho+\frac{d}{a}+\frac{B}{b}\right)+0.212 \times \sqrt{\rho_{w} \cdot F_{y w} \times F_{c 28}} & \frac{a}{d} \leq 2 \\
q_{u}=q_{c r}+1.92 \times\left(100 \rho+\frac{d}{a}+\frac{B}{b}\right)+0.0785 \times \rho_{w} \cdot F_{y w} \times \sqrt[3]{F_{c 28}} & 2<\frac{a}{d} \leq 4
\end{array}
$$

FOR BEAMS WITHOUT WEB REINFORCEMENT:

$$
\mathrm{q}_{\mathrm{u}}=\mathrm{q}_{\mathrm{cr}}+5.47 \times \sqrt[4]{\mathrm{F}_{\mathrm{c} 28}}-39.68 \times \mathrm{S} \times \rho
$$


The values of ultimate shear strength by using above equations in addition to the results of ultimate shear strength are represented in Fig. (11).

\section{COMPARISON OF SHEAR STRENGTH OF THE TESTED BEAMS WITH SOME AVAILABLE AND IMPORTANT EQUATIONS}

Many equations have bean derived for calculating the cracking and ultimate shear strength in reinforced concrete beams. A comparison between the predicated values of shear strength by using the proposed equations and those proposed in ACI-code, Zsutty's equation, and Egyptian code equations are presented.

\section{Cracking Shear Strength Egyptian Code Equations}

The cracking value of shear strength for T-beams having different grades of concrete compressive strength can be given by equation (1). It is appears that in this equation the cracking shear strength is depending on concrete compressive strength only.

\section{Ultimate Shear Strength}

\section{American Concrete Institute}

In the ACI. Code, the value of ultimate shear strength, $q_{u}$, is calculated from equations (5) and (6).

\section{Zsutty's Equation:}

Zsutty derived equations (8) and (9) for predicting the ultimate shear strength, $q_{u}$.

\section{Egyptian Code Equation}

In the ECCS 203-2001 Code, the value of ultimate shear strength, $q_{u}$, is calculated from equation (2). The obtained values of $\mathrm{q}_{\mathrm{u}}$ from proposed equation and predicted values by ACI Code and Zsutty's equations are given in table (4) and Fig. (11). Also compression between the different values of the ultimate cracking shear strength, $\mathrm{q}_{\mathrm{u}}$ is presented in the same table.

From table (4) and Figs. (11), its appears that ACI. Code equation is conservative for most values that it underestimates the importance of both shear spane to depth ratio, and longitudinal steel ratio, flange to web width ratio. Also, it can notice that Zsutty's equations describe ultimate shear strength for the test results with the maximum error for low values of concrete compressive strength about $4.29 \%$. Comparing the test results by the predicted results by ECCS 203, equations. It is appears that ECCS 203 equation dose not estimated the ultimate shear strength that it has a constant value of ultimate shear strength equals $28.4 \mathrm{Kg} / \mathrm{cm}^{2}$ for beams having $\mathrm{F}_{\mathrm{c} 28}$ equals to $250 \mathrm{Kg} / \mathrm{cm}^{2}$.

The ECCS 203, Code equation not take into consideration the effect of shear span to depth ratio, $a / d$, longitudinal steel ratio, $\rho$, flange to web width ratio, 
$B / b$, in additional to this equation not to be virtuous to beams made from high strength concrete.

Table (4): Comparison between ultimate shear strength obtained by the proposed equation and that obtained by available equations and codes

\begin{tabular}{|c|c|c|c|c|c|c|c|}
\hline \multirow{2}{*}{$\begin{array}{l}\text { Beam } \\
\text { No. }\end{array}$} & \multicolumn{4}{|c|}{ Ultimate shear stress $\mathrm{kg} / \mathrm{cm}^{2}$} & \multirow{2}{*}{$\mathbf{q}_{\mathrm{u} \text { test } /} \mathbf{q}_{\mathrm{ACI}}$} & \multirow{2}{*}{$\underset{\text { test } / \mathbf{q}_{\text {zsutty }}}{\mathbf{q}_{\mathbf{u}}}$} & \multirow{2}{*}{$\begin{array}{c}\mathbf{v}_{u} \text { eqn } \\
\text { test }\end{array}$} \\
\hline & Test & $A C I$ & Zsutty & Eqn. 3.4 & & & \\
\hline $\mathrm{A}_{1-1}$ & 41.6 & 22.76 & - & 41.161 & 1.83 & - & 1.011 \\
\hline$A_{1-2}$ & 38.36 & 22.51 & 37.02 & 38.538 & 1.70 & 1.04 & 0.995 \\
\hline$A_{1-3}$ & 28.42 & 22.42 & 28.3 & 23.998 & 1.27 & 1.00 & 1.184 \\
\hline $\mathrm{A}_{1-4}$ & 21.35 & 22.38 & 26.45 & 22.787 & 0.95 & 0.81 & 0.937 \\
\hline $\mathrm{A}_{2-1}$ & 31.56 & 16.48 & - & 29.497 & 1.92 & - & 1.070 \\
\hline $\mathrm{A}_{2-2}$ & 25.67 & 16.22 & 27.71 & 25.904 & 1.58 & 0.93 & 0.991 \\
\hline$A_{3-1}$ & 29.00 & 17.68 & 30.04 & 29.867 & 1.64 & 0.97 & 0.971 \\
\hline$A_{3-2}$ & 31.5 & 19.52 & 32.82 & 34.018 & 1.61 & 0.96 & 0.926 \\
\hline$A_{3-3}$ & 34.2 & 21.10 & 35.08 & 36.419 & 1.62 & 0.97 & 0.939 \\
\hline $\mathrm{B}_{1-1}$ & 30.53 & 22.51 & 37.02 & 33.329 & 1.36 & 0.82 & 0.916 \\
\hline $\mathrm{B}_{1-2}$ & 37.62 & 22.51 & 37.02 & 35.934 & 1.67 & 1.02 & 1.047 \\
\hline $\mathrm{B}_{1-3}$ & 41.26 & 22.51 & 37.02 & 41.143 & 1.83 & 1.11 & 1.003 \\
\hline $\mathrm{B}_{1-4}$ & 17.6 & 22.38 & 26.45 & 17.736 & 0.79 & 0.67 & 0.992 \\
\hline $\mathrm{B}_{1-5}$ & 20.7 & 22.38 & 26.45 & 20.111 & 0.93 & 0.78 & 1.029 \\
\hline $\mathrm{B}_{1-6}$ & 22 & 22.38 & 26.45 & 25.765 & 0.98 & 0.83 & 0.854 \\
\hline $\mathrm{C}_{1-1}$ & 31.4 & 14.51 & 28.98 & 30.239 & 2.16 & 1.08 & 1.038 \\
\hline $\mathrm{C}_{1-2}$ & 37.16 & 19.02 & 33.49 & 34.277 & 1.95 & 1.11 & 1.084 \\
\hline $\mathrm{C}_{1-3}$ & 39.2 & 27.07 & 41.53 & 42.776 & 1.45 & 0.94 & 0.916 \\
\hline $\mathrm{C}_{1-4}$ & 19.24 & 14.38 & 18.41 & 20.257 & 1.34 & 1.05 & 0.950 \\
\hline $\mathrm{C}_{1-5}$ & 20.51 & 18.89 & 22.92 & 20.216 & 1.09 & 0.89 & 1.015 \\
\hline $\mathrm{C}_{1-6}$ & 21.71 & 26.94 & 30.96 & 26.075 & 0.81 & 0.70 & 0.833 \\
\hline$D_{1-1}$ & 37.8 & 22.43 & 33.76 & 36.234 & 1.69 & 1.12 & 1.043 \\
\hline $\mathrm{D}_{1-2}$ & 35.6 & 22.36 & 30.17 & 34.296 & 1.59 & 1.18 & 1.038 \\
\hline $\mathrm{D}_{1-3}$ & 35.3 & 22.31 & 26.21 & 32.777 & 1.58 & 1.35 & 1.077 \\
\hline $\mathrm{D}_{1-4}$ & 20.81 & 22.34 & 24.37 & 20.873 & 0.93 & 0.85 & 0.997 \\
\hline$D_{1-5}$ & 20.33 & 22.31 & 22.10 & 19.222 & 0.91 & 0.92 & 1.058 \\
\hline$D_{1-6}$ & 19.36 & 22.28 & 19.58 & 17.875 & 0.87 & 0.99 & 1.083 \\
\hline
\end{tabular}




\section{CONCLUSION}

1- The final mode of, initial cracking and ultimate shear strength of high strength concrete T-beams are mainly affected by shear span to depth ratio, flange to web width ratio, longitudinal steel ratio, and concrete compressive strength.

2- Web reinforcement has no effect on the cracking shear strength of T-beams made from high strength concrete.

3- For T-beams failing in shear, the value of cracking shear strength, $q_{c r}$, in S.I unites can predicted using the following equations:

$$
\begin{array}{lr}
\mathrm{q}_{\mathrm{cr}}=36.18 \times \rho \times \mathrm{S}+0.715 \times \sqrt[3]{\mathrm{F}_{\mathrm{c} 28}} & \frac{\mathrm{a}}{\mathrm{d}} \leq 2 \\
\mathrm{q}_{\mathrm{cr}}=1.413 \times \sqrt{\rho} \times \mathrm{S}^{2}+0.4 \times \sqrt[3]{\mathrm{F}_{\mathrm{c} 28}} & 2<\frac{\mathrm{a}}{\mathrm{d}} \leq 4
\end{array}
$$

Where $S$ is dimension less factor $=(d / a) \times(B / b)$

$$
\mathrm{q}_{\mathrm{u}}=\mathrm{q}_{\mathrm{cr}}+2.08 \times\left(100 \rho+\frac{\mathrm{d}}{\mathrm{a}}+\frac{\mathrm{B}}{\mathrm{b}}\right)+0.212 \times \sqrt{\rho_{\mathrm{w}} \cdot \mathrm{F}_{\mathrm{yw}} \times \mathrm{F}_{\mathrm{c} 28}} \quad \frac{\mathrm{a}}{\mathrm{d}} \leq 2
$$

4- Ultimate shear strength of reinforced concrete T-beams is directly proportional to cracking shear strength and web reinforcement factor.

5- For T-beams that failing in shear under static loading, the value of ultimate shear strength in S.I. units can predicted using the following equations:

For beams with web reinforcement :

$$
\mathrm{q}_{\mathrm{u}}=\mathrm{q}_{\mathrm{cr}}+1.92 \times\left(100 \rho+\frac{\mathrm{d}}{\mathrm{a}}+\frac{\mathrm{B}}{\mathrm{b}}\right)+0.0785 \times \rho_{\mathrm{w}} \cdot \mathrm{F}_{\mathrm{yw}} \times \sqrt[3]{\mathrm{F}_{\mathrm{c} 28}} \quad 2<\frac{\mathrm{a}}{\mathrm{d}} \leq 4
$$

For beams without web reinforcement:

$$
\mathrm{q}_{\mathrm{u}}=\mathrm{q}_{\mathrm{cr}}+5.47 \times \sqrt[4]{\mathrm{F}_{\mathrm{c} 28}}-39.68 \times \mathrm{S} \times \rho
$$

6- The values of ultimate shear strength of analyzed beams show remarkable difference in comparison with the corresponding recommended values given in the ACI. Code equation.

7- The predicted values of ultimate shear strength by Zsutty's equation slightly agree with that achieved by analyzed beams.

8- The values of cracking and ultimate shear strength of analyzed beams show disagreement with the corresponding values of adopted values of Egyptian code equations. 


\section{REFERENCES}

[1] Egyptian code of concrete practice, 2001.

[2] M. H. Mansour, "Structural Analysis of R.C. Beams In Three Dimensions", M. Sc., Thesis, Assiut University, Egypt, 1999

[3] ACI manual of concrete practice, 1994.

[4] Zsutty T., (1971), "Shear strength prediction for separate categories of simple beam tests" ACI Journal Vol. 68, No. 2, February.

[5] Khaled A. Mahmoud, Kamal A. Assaf, Yehia H. Hassanean and A. Megahid "predection of shear strength of high strength reinforced concrete tee beams.

[6] Nilson, A.H., "Nonlinear Analysis of Reinforced Concrete bythe Finite Element Method", ACI Journal Vol. 65 No. 757-766, September 1968.

[7] Vechio, F. J., "Nonlinear Finite Element Analysis of Reinforced Concrete Members", ACI Structural Journal, Vol. 86, No. 4, January-February 1989.

[8] Aly A.G. and Soghair, H.M., "Analysis of R.C. Beams”, Eng., Res. Journal, Vol. 48, May 1996.

[9] Chen, W. "Plasticity in Reinforced Concrete", MC. Graw-Hill Bock Co. 1982.

[10] M. M. Hashem, "Shear Response of Reinforced Concrete T-Beams to Static and Repeated Loads" M. Sc., Thesis, Assiut University, Egypt, 1979.

[11] Kamal A. Assaf, (1986) The "Behavior of R.C. beams of L-Section under static and repeated loads" M.Sc. Assiut University.

[12] Kim J. K. and Park Y. D., (1994), "Shear strength of reinforced high strength concrete beams without web reinforcement "Magazine of concrete research, Vol. 46, No. 166, March.

[13] Salandra M. A. and Ahmed S. H., (1989), "Shear capacity of reinforced concrete lightweight high strength concrete beams" ACI journal, Vol. 86, No. 6, November-December.

[14] Sung-Woo S. Kwang-Soo L. Jung-Moon and S. K. Ghosh, (1999), "Shear strength of reinforced high strength concrete beams with shear span to depth ratio between 1.50 and 2.50" ACI Journal Vol. 96, No. 5, July-August.

[15] Yoon, Y. S., Cook W. D. and Mitchell D., (1996), "Minimum shear reinforcement in normal, medium and high strength concrete beams" ACI Journal Vol. 93, No. 5, September-October. 
[16] Zhang J. P., (1997), "Diagonal cracking and shear strength of reinforced concrete beams" Magazine of concrete research, Vol. 49, No. 178, March.

\section{سلوك القص للكمرات الخرساتية المسلحة ذات المقاومة العالية ذات مقطع علي شكل حرف T تحت تأثير الأحمال الاستاتيكية} الغرض من هذا البحث هو استتباط معـادلات للتتبؤ بقيم مقاومـة القص للكمرات ذات مقطع علي شكل حرف T والتي تتهار بسبب قوى القص روذلك لدراسـة سلوك هذا النوع من الكمرات، و تأثثر العوامل الآتية علي هذه سلوك هذه الكمرات تحت تأثنير الأحمال الاستاتيكية :

أ - - - نسبة بين بحر القص إلى العمق الفعال للكمرة.

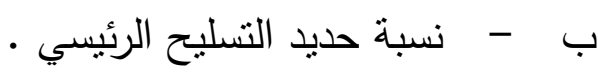
جـ - مقاومة الضغط للخرسانة. د - - مسبة حديد تسليح القص. هـ - نسبة عرض الثفة إلى عرض الجزع في الكمرات ذات مقطع علي شكل حرف . $\mathbf{T}$ استخدمت نظرية العناصر المحدودة لاختبار ستة وعشرون كمرة خرسانية، وتم مقارنة ثم تم تحليل ومناقثـة النتائج لدراسـة سلوك هذه الكمرات تحت تأثير قوي القص من ناحية

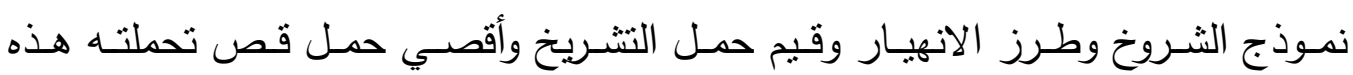

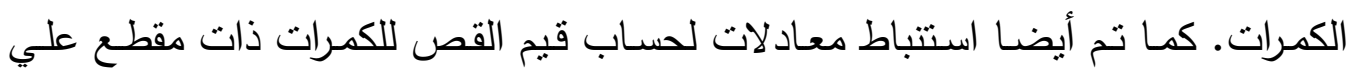
شكل حرف T. ثُ تم مقارنة قيم مقاومة القص المحسوبة بهذه المعادلات مع قيم مقاومة القص المحسبة باستخدام كل من الكود المصري ECCS 203-2001 والكود الأمريكي 